\title{
Saving for a Sunny Day
}

Why should people-and economies-save? The typical answer usually focuses on the need to protect against future shocks, to smooth consumption during hard times, in short, to save for the proverbial rainy day. This book approaches the question from a slightly different angle. While saving to survive the bad times is important, saving to thrive in the good times is what really counts. People must save so they can invest in their own and their children's health and education, live productive fulfilling lives, and end their days in comfort and peace. Firms must save so they can grow productive enterprises that employ more workers in better jobs to produce quality goods for domestic and international markets. Governments must save to build bridges, highways, and airports that support a productive economy, to provide quality services such as education, health, water, and sanitation to their citizens, and to assure their senior citizens a dignified, worry-free retirement. In short, countries must save for a sunny day-a time when everyone can bask in the benefits of growth, prosperity, and well-being.

To have even a chance of reaching that sunny day, this book argues that Latin America and the Caribbean must save more and save better. It contends that saving in the region is too low and that the savings that do exist can be used more efficiently to enhance growth and development. The purpose of this book is to raise awareness about the urgent need to promote more and better saving to address several of the region's most pressing issues including lackluster growth, low investment rates, and the growing need to care for an aging population.

Why should economies care about how much they save? After all, if economies can always borrow from abroad, then national saving rates should not matter. However, borrowing from abroad may be more costly and may raise the risk of crises. Foreign financial flows are fickle, and history shows that they dry up just when they are needed most. Latin 
America and the Caribbean is no stranger to the currency and financial turmoil generated by external debt. Importing saving from abroad is far from a perfect substitute to boosting saving at home.

Given the limits to external borrowing, countries that save more also invest more. In other words, there is a positive association between national saving and domestic investment (investment in the real economy, not purely financial investment). From a policy perspective, it is useful to understand which drives which: whether higher saving leads to more real investment or whether better investment opportunities lead to increases in saving. This book argues that causality runs in both directions. Or more precisely, that Latin America and the Caribbean suffers from two reinforcing problems: low saving supply and weak investment demand. Solving these problems and breaking the vicious cycle between them demands concerted and swift policy action to increase saving and investment.

\section{Savings: The Sum of its Parts}

National saving is the sum of all the individual saving decisions of the agents in the economy: households, firms, and government agencies. While a macroeconomic analysis is instructive, in the end saving decisions are made by individuals and reflect the information they have and the many real-life considerations that may influence their behavior. To fully understand the problem of saving, it is imperative to break down and analyze how the savings generated by households, firms, and government agencies is aggregated and channeled to the economy.

The financial system is the middle man: it moves the resources from people who save to those who need the resources to invest. Small and inefficient financial systems, like those in Latin America and the Caribbean, jack up the costs for financial services, which in turn depress both saving (by reducing effective returns to savers) and investment (by increasing the cost of credit to borrowers). In such contexts, households that lack access to good financial savings instruments may opt to save in other ways-by accumulating cash or jewelry, by buying durable goods, or by investing in the family firm - which may not be the most productive. These mechanisms reduce the collective efficiency with which the existing savings are used. A good financial system not only mobilizes savings but also pools them and allocates them efficiently to finance the projects with the highest returns. If savings are not pooled within a 
well-functioning financial system, then the overall economy suffers a loss, as do the individuals and firms in that economy. Efficient financial intermediation encourages more saving and ensures that savings are used in the most productive fashion, supporting growth and development.

Despite the financial deregulation and reforms of recent decades, financial systems in Latin America and the Caribbean remain very shallow by international standards. While the median banking system in the region has grown to provide approximately 30 percent of GDP in loans to the private sector, this level remains much lower than the banking systems of the median OECD or Emerging Asia economy, which provide approximately 80 and 100 percent of GDP in loans to the private sector, respectively.

Households in the region, especially lower-income households, have limited access to adequate financial instruments to save. They face relatively high costs to access and use the available instruments and often do not trust formal banks. As a result, households save less than they otherwise would; or when they save, they do so using nonfinancial vehicles.

The lack of development and coverage of pension systems in the region is another severe constraint for saving. Less than half the population in Latin America and the Caribbean saves for retirement through a contributory pension system. Households simply do not save enough for retirement, and do not make up for the lack of pension saving through nonpension saving instruments. This situation is a crisis in the making that will worsen as the region inevitably ages. Pension regimes by and large have failed to prepare countries for the demographic transition underway in their societies. In addition to low pension coverage, extensive labor informality, widespread financial illiteracy, and lack of trust in financial systems seriously hamper household saving.

In the case of firms, saving decisions are intimately connected to their investment needs. Firms save (that is, retain earnings) because internal funds are cheaper: they are free from the intermediation costs of bank credit. When the cost of external credit is too high, self-financing may become the only feasible way for firms to finance investments. But when firms lack sufficient retained earnings or external credit in the form and amount they need, they forego productive opportunities. Removing distortions in financial markets that prevent firms from accessing the funding they need at a reasonable cost would enable firms to take on productive investment projects with high returns. This, in turn, would encourage more saving, as both households and firms would want to save more to benefit from the higher returns to investment. 
Distortions in labor and product markets also set the stage for misallocating economic resources and, therefore, limiting productivity growth. Scores of small, informal, and unproductive firms in Latin America and the Caribbean limp along on the crutches of lower input costs or higher product prices thanks to taxes and poorly enforced regulations. Removing these preexisting distortions would put everyone on an even footing, improve the business environment, boost investment and, eventually, saving.

Government agencies also save. The political economy literature abounds with theories as to why governments consume too much and save and invest too little. Governments with short time horizons may shy away from long-term investments. Governments with windfall revenues (say, from commodity price booms) may be tempted to dole out the proceeds to their constituencies today, rather than risk others spending in a different fashion tomorrow. Adding to the problem, governments tend to spend inefficiently. Subsidies and/or social transfer programs may be poorly targeted, or the quality of spending is low. These inefficiencies lead to government overspending. Reducing spending inefficiencies would amount to increasing public saving: more money would be freed up for higher quality and more productive public outlays.

Impediments and distortions to saving by households, firms, and government agencies take a toll on the efficiency with which available savings are used. The absence of long-term saving instruments can steer investments away from projects with long horizons that are necessary to raise economic productivity and growth.

A case in point is infrastructure investment such as ports, roads, railways, energy, communication networks, and water and sanitation. Latin America and the Caribbean suffers from the dual problems of low-quality physical infrastructure and insufficient annual investment to close the infrastructure gap. The region must increase investment by between 2 and 4 percentage points of GDP per year for decades to loosen this binding constraint on growth. Low national saving limits the financing available for building and maintaining productive infrastructure. Poor infrastructure, in turn, results in the inadequate provision of services such as potable water, sanitation, health, communications, transportation, and even public safety. These deficiencies prevent households from living the productive, healthy lives that they aspire to. It also slows entrepreneurs with good ideas from expanding their businesses and adding capital and high productivity jobs to the economy. 
Saving also matters to the day-to-day life of individuals. Households that either do not save, or save primarily through informal mechanisms, usually have more difficulty dealing with shocks such as losing a job or illness; it is harder for them to invest in education or other forms of human capital; and they do not have the reserves to ride out hard times (smooth consumption). For many individuals, it is too difficult to save when they struggle to make ends meet. However, low-income households do need adequate saving instruments; the problem is that they are not available.

On top of all these pressing needs, the population of Latin America and the Caribbean is aging fast. For the past four decades, most countries in the region have benefited from a bonus in the form of an increase in the working-age population. More workers made it easier to take care of a relatively smaller pool of elderly people through intergenerational transfers (either arrangements within the family, or to a lesser extent, through pensions). This bonus has now ended in many countries, or will end very soon for the rest. Population graying will fuel the demand for resources to meet the greater needs of an expanding group of elderly people. The policy challenge is to ensure that the necessary savings are mobilized now. The alternatives are sad indeed: siphon off more resources from a shrinking working-age population through significantly higher taxes, or face the moral challenge of relegating a large share of the elderly population to live in poverty. The region's aging is inevitable. Saving now is an antidote for the looming aging crisis.

\section{Why Care about National Saving?}

National saving is the vehicle through which the region can become stable and confident in its own future. Yet countries in Latin America and the Caribbean are falling short of this goal. They save less than 20 percent of their national income. By contrast, the high-growth countries in East Asia save about 35 percent of national income. Latin America and the Caribbean saves less than every other region in the world, except Sub-Saharan Africa. At the same time, investment rates are lower than what would be needed to sustain high rates of economic growth. ${ }^{1}$ The region is not putting aside enough resources today to build a better, brighter future.

Can countries substitute low national saving rates by importing savings from abroad? Not perfectly. Few countries have been able to import savings for prolonged periods of time without abrupt reversals or without 
incurring severe external indebtedness problems that lead to recurrent financial crises. Crisis-related volatility generates disincentives to save locally because the real value of savings usually falls after crises. People naturally want to protect the real value of their hard-earned savings; thus, they often channel savings abroad, purchase durable goods, or step up consumption rather than invest locally when there is too much volatility. High volatility may also discourage foreigners from lending at longer terms and lower cost. A negative cycle sets in whereby low national saving fuels the need for more foreign savings, which becomes ever more difficult to attract, increases external borrowing costs, induces financial fragility and crises-and feeds back into another shaky cycle. Mobilizing national saving would help break the cycle and set into motion the opposite dynamic. Foreign saving can be a necessary and useful complement to national saving, but it is far from a perfect substitute.

\section{Sharing the Blame for Low Saving}

Demographic factors-such as the number of working to non-working age people in a country at a given point in time-matter for saving. Are demographic factors to blame for the region's low saving rates? The answer is no. Beginning in the 1960s, the region embarked on a "saving-friendly" demographic transition (with decreasing age dependency ratios), very much like high-saving countries in Asia. In 1965, for each 100 individuals of working age, there were 90 dependents, either young or old; today there are fewer than 50.Yet, unlike Asia, national saving rates in Latin America have not increased much. If favorable demographic factors had been fully exploited, the average saving rate in Latin America and the Caribbean should be about 8 percentage points of GDP higher. ${ }^{2}$

Various nondemographic factors have kept the saving rates in the region from rising, despite the demographic bonus. One is the lack of adequate saving instruments. The perennial problems of lack of trust in financial institutions and high costs of doing business with banks discourage households from placing their savings in formal financial institutions. Only about 16 percent of the adult population in Latin America and the Caribbean report saving through a bank, compared to 40 percent in Emerging Asia, and 50 percent in advanced economies. ${ }^{3}$ Instead, households in the region-especially relatively poorer households- save more through informal mechanisms, or just give up on saving altogether. 
Another factor that has depressed saving is the state of the region's pension systems. They cover less than half the population, and many of them face long-term sustainability challenges. Most people in Latin America and the Caribbean do not save through pension systems, or they do not save for enough years to qualify for a contributory pension at the end of their working lives. Importantly, they do not make up for the lack of pension contributions with higher voluntary saving. The pension crisis in Latin America and the Caribbean is effectively a saving problem, with serious social implications.

Fiscal policy has also been a drag on saving in the region. Two longstanding problems of public finance remain largely unaddressed and have a direct bearing on public saving. First, the composition of public expenditures is more oriented toward current expenditure (consumption) than to public investment (saving). Distorted incentives bias public expenditures toward current spending and away from capital investment over the economic cycle. In good times, political economy incentives encourage governments to increase spending across the board. In bad times, it is usually politically more expedient for governments to cut (or postpone) capital expenditure projects than to reduce other expenditures. For example, total expenditure in Latin America and the Caribbean from 2007 to 2014 increased by a very significant 3.7 percent of GDP, but more than 90 percent went into current expenditure, and only 8 percent was devoted to longer-term public investment.

Second, there is considerable leakage in spending areas such as social assistance, tax expenditures and subsidies to energy that average about 2 percent of GDP in the region. In addition, inefficiencies in health and education expenditures average approximately 1 percent of GDP. These leakages and inefficiencies are in essence public saving that is forgone. In good times, nobody pays much attention to these inefficiencies because they are hidden behind positive headline fiscal numbers. But when tax revenues fall, these inefficiencies loom large.

Taxation also directly impacts saving because tax revenue is one of the components of public saving (see Box 1.1). And it indirectly impacts saving through the incentives it provides to individuals and firms to save. Widespread tax evasion in the region is a problem on both fronts: it reduces tax revenues, and it distorts the incentives of compliers versus noncompliers. Tax evasion is, on average, about 52 percent of potential tax collection in Latin America: that is, about half of potential revenues are lost through tax evasion. ${ }^{4}$ 


\section{BOX 1.1. DEFINING SAVINGS AND ITS COMPONENTS}

Total saving in an economy is the current national income that is not consumed. Therefore, it is equal to domestic (real) investment. In turn, total saving can be broken down into national and foreign saving. National saving is the sum of the saving of households and firms plus the saving of public sector agencies. Foreign saving is the net capital that inflows to the economy (that is, net external borrowing). Figure B1.1 illustrates these fundamental accounting relationships.

Total saving has two main components: gross national saving (GNS) and foreign saving (FS).

Gross national saving is the national income (gross national income, GNI) minus private and public consumption ( $C$ and $G$, respectively). Private saving is GNI minus taxes ( $\mathrm{T}$ ) minus private consumption (C). Public saving is taxes $(\mathrm{T})$ minus public consumption ( $\mathrm{G}$ ).

Foreign saving is equal to the current account deficit (CAD) in the balance of payments. This is the net of gross capital inflows to the economy (defined as the changes in the stock of international liabilities) and gross capital outflows from the economy (defined as changes in the stock of foreign asset holdings by residents).

\section{Figure B1.1 Fundamental Accounting Relationships of Savings}

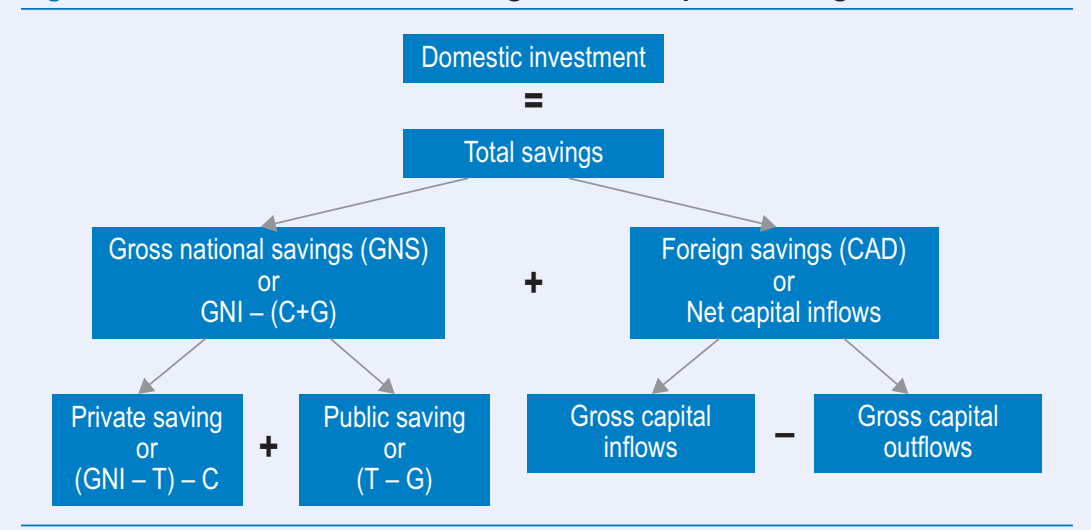

Note: $\mathrm{C}$ = private consumption; $\mathrm{CAD}=$ current account deficit; $\mathrm{G}=$ public consumption; $\mathrm{GNI}=$ gross national income; $\mathrm{T}=$ taxes.

The result is a misallocation of economic resources and lower aggregate productivity. This, in turn, generates disincentives to save because an economy with low productivity growth is essentially an economy in which returns to saving and investment are also low. Distortions beyond financial markets also matter for productivity growth and saving. Labor markets distorted by high levels of informality, inefficient or inequitable 
social policy regulations, special tax regimes, or a combination of these factors, change the private profitability of investment projects and lead to socially inefficient investments. Removing these distortions would increase productivity, investment, and savings.

\section{How to Promote Saving for Development}

This book outlines how to increase saving for the future in sustainable ways. A comprehensive agenda to mobilize saving combines public policies to stimulate saving directly, such as measures related to fiscal policy and pensions, with policies that operate indirectly by removing constraints that impede agents from saving-and particularly from saving efficiently, in ways that support economic growth and welfare. Improving the efficiency with which savings are used also requires eliminating the distortions that waste economic resources and restrain productivity growth-and thus reduce investment demand.

Tackle the pension problem. A solution to Latin America's saving problem requires fixing broken pension systems. Countries in the region have promised to pay very generous pensions to their retirees, but they have not saved enough to fulfill those promises for everyone. Most pension systems in the region face structural challenges associated with informality and low contribution rates. The public debate in the region largely revolves around whether pension systems should be based on individual accounts (fully funded) or pay-as-you-go (PAYG) approaches. However, that is not necessarily the most relevant debate.

Countries with pension systems based on individual saving accounts-or that want to move in that direction-must realize that these systems per se cannot resolve their saving woes. First, if too few people are covered or contribute to the system, and/or contributions throughout the working life of an individual fall short of providing adequate pension benefits at retirement (either because contributions are low or because the returns to those contributions during the investment period are low), then the government will have to shell out resources to make up the deficit. This will continue to be a drag on national saving. Moreover, transition costs have piled up from shifting pension systems from pay-as-you-go structures (which is how all pension systems in the region began) to systems based on individual accounts because the commitments made to contributors under 
the pay-as-you-go systems must be fulfilled. This can be a substantial drain on public resources.

Countries with pay-as-you-go systems must adjust the systems' parameters (such as the retirement age, level of benefits, and required years of contributions) to avoid unfunded and/or unsustainable systems down the road. So far, the problem has been hidden behind favorable demographic trends (with relatively more contributors to the pool than retirees receiving benefits). Yet despite the favorable demographics, pay-as-you-go systems have not built adequate reserves by saving (and investing) the excess contributions. Pay-as-you-go pension systems should and must save, creating adequate reserve funds to ensure their long-run sustainability. Importantly, the inevitable fixes to the systems' parameters should come before expanding benefits to more people; otherwise, adding beneficiaries, without addressing the underlying problems of the system, increases the demands on a shrinking pool of resources.

Because pension coverage is inadequate in the two types of contributory pension systems that coexist in Latin America and the Caribbean, noncontributory pension programs are proliferating. Noncontributory pensions provide payments to people who have either not contributed, or do not qualify for a contributory pension. Today, noncontributory pensions account for one-third of pension coverage in the region. In several countries, more people receive noncontributory pensions than contributory pensions. The noncontributory pensions with the highest coverage cost between 0.7 percent and 1 percent of GDP. This cost will more than double by 2050 if generosity and coverage remain constant, just to account for changes in demographics.

The possible effects that noncontributory pensions may have on incentives to save are also important. The emergence of these pensions has yielded some very relevant insights into how individuals and households react to changes in benefits. Noncontributory pensions steal beneficiaries away from contributory systems, and in some cases decrease their savings. They also reduce the transfers that beneficiary households receive from other households. ${ }^{6}$ To minimize unintended negative consequences on saving either through excessive fiscal costs, or indirectly by crowding out saving, these programs must be carefully designed and funded, and targeted only to the population at risk of oldage poverty.

Increasing pension saving can also help solve another perennial problem of the region: the lack of long-term funding in local currencies 
available to finance investment. Infrastructure investment is a highly productive form of investment in short supply in Latin America and the Caribbean. To be viable and sustainable over time, infrastructure investment requires long-term financing-precisely the type of financing that comes with national saving. As countries raise pension saving, the accumulated resources-which by definition are locked up for some time-can be increasingly channeled to finance infrastructure investments.

To do so, policymakers in the region must set up the rules of the game. The first step is to promote the development of an "investible asset class" that permits accumulated savings to be channeled into investment in infrastructure. Since well-planned and executed infrastructure investment is highly productive, the returns on saving generated by these investments can potentially be very large and support the longterm sustainability of pension systems.

However, the region is starting from a very low point, as many countries still have amassed few resources in pension funds, particularly in countries with pay-as-you-go systems. Therefore, the expectation that higher pension saving by itself will solve the region's infrastructure gap is unrealistic.

Focus on infrastructure and capital spending. To increase investment to close the infrastructure gap, the region needs to boost public saving and investment. The public sector is the main source of financing for infrastructure investment in the region and in the world. Increasing public investment requires designing fiscal rules and targets that direct a higher share of total expenditures to public investment and counter the political economy forces that bias expenditures toward current expenditures in both good and bad times.

Over the last two decades, improved fiscal frameworks have delivered higher public saving in many countries. Yet more effort is needed just when a challenging economic environment has made doing so more difficult. The good news is that substantial public saving can still be generated without having to rely on the traditional tools of raising taxes or reducing expenditures across the board.

First, governments must realize that the composition of public expenditures is a direct determinant of the level of public saving. Governments have room to boost public saving by increasing the share of capital expenditures, which is low in the region, with respect to current spending, which is high. This requires a more prudent approach 
to fiscal policy. As a general rule, only a small fraction of any change in commodity prices or other external factors should be considered permanent. Then, current expenditures will be expanded relatively less in good times (the upside of the typical business cycle) and reduced more in the downturns.

Second, savings of approximately 2 percent of GDP on average could be generated by reducing leakage in current expenditures in areas such as social assistance, tax expenditures, and subsidies to the energy sector. That means making sure that spending reaches its intended beneficiaries only. Designing and implementing reforms to make public expenditures more efficient should rank high on the policy agendas of governments throughout the region.

Target tax policy better. Governments can also encourage saving through tax policy. Income taxes are levied on both individuals (personal income tax) and firms (corporate income tax). But households collectively own firms; therefore tax policy should consider integrating personal and corporate income taxes, and avoiding double taxation of savings: first, when it is generated by the firm, and then when it is distributed to households as dividends. ${ }^{7}$ Personal income taxes across the region should continue evolving into a dual system, ${ }^{8}$ with a lower flat tax on capital, in which all forms of capital income (interest payments, dividends, and capital gains) receive equal tax treatment. Corporate income tax rates should fall in line with international trends to facilitate the formalization of informal firms. ${ }^{9}$ This would help expand the tax base, which is currently low. ${ }^{10}$

Countries in the region must also reconsider tax preferences that favor investing in housing rather than financial instruments such as stocks, bonds, and term deposits in banks. Loopholes in the tax codes in many countries discriminate against nonhousing saving vehicles while mostly benefiting high-income households. Leveling off tax incentives for housing with other forms of financial saving is generally a better option than introducing new tax incentives for certain types of financial saving. In the past, many advanced countries introduced tax-preferred savings accounts, sometimes designed to encourage saving for education, life insurance contracts, and other purposes. The evidence shows that these tax preferences did not increase saving. By and large, only the relatively rich used these vehicles, primarily to reduce their tax payments, with limited to no impact on total saving. ${ }^{11}$ 
Promote household saving and create a savings culture. At the household level, saving rates in the region are distorted by a number of factors: high costs of accessing and using the financial system; lack of confidence in the financial system; poor financial regulation; little understanding about banks and how they work; and social pressures and behavioral biases. Successful financial inclusion requires more than just opening new bank accounts. It means tailoring saving products to the demands of potential clients, taking into account the various real-life constraints they face to save, and creating incentives to channel more savings through the formal financial system. Preliminary but encouraging evidence of public policy interventions and financial product innovations shows an increase in household saving, as well as promising initiatives to encourage more financial saving in particular. Making more and faster progress in these areas requires more dynamic regulation and supervision of the financial system and the collaborative efforts of financial regulators and bankers to implement reforms and promote even more innovation.

Government initiatives to pay social transfers through bank accounts and to channel remittances through domestic financial systems are useful first steps. Additional progress in encouraging more financial saving demands improvements in the design of the programs: for example, by pairing payments with programs that provide financial education, and/ or with instruments to help users overcome the behavioral and social biases that constrain saving. Innovation and technology provide another opportunity to encourage more saving through the formal financial system. While the penetration of mobile telephones is high in Latin America and the Caribbean, the region still lags behind in using mobile technology for financial services and as a tool for financial inclusion because policy and regulations have not kept pace with the mobile telephone revolution.

A promising avenue for creating a saving culture in Latin America and the Caribbean is financial education, with a focus on children and youth. Positive saving habits are easier to instill during the early years, when the brain is still developing and learning is easier.

Improve productivity growth. Increasing national saving is necessary to achieve the region's aspirations, but it is not enough. Evidence from around the world shows that historically, an increase in national saving rates coincided with higher economic growth only when the saving surges were accompanied by higher aggregate productivity growth. 
This relationship underscores two points. First, a surge in saving rates can be sustained for long periods of time when it is associated with permanent incentives for individuals to save. And the incentives to save are higher when productivity grows faster. Second, in order for more saving to impact growth and development, the savings must be put to good use. That is, savings must be channeled to productive investment opportunities.

Total factor productivity (TFP) is ultimately the weighted sum of the productivity of the existing population of firms in the economy. TFP can grow because either firms in the economy become more productive, more resources are channeled to productive firms, or the market allows more productive firms to survive and less productive firms to exit. Latin America and the Caribbean is cluttered by a large number of small, informal, and unproductive firms that survive because they enjoy cheaper inputs and/or higher product prices. These factors, in turn, arise from distortionary taxes and regulations that are not properly enforced. Increasing aggregate productivity requires reducing those distortions. Doing so would improve the allocation of resources in the economy and increase aggregate saving and investment.

Fix the financial system. Efforts to create and sustain a culture of saving in the region must be complemented by efforts to help the financial system pool and allocate savings efficiently. Only by fixing the problems that discourage the use of financial systems for saving and limit the availability of financing for productive firms, can more saving turn into better saving for development.

Financial frictions are like sand in the wheels of the economy; they slow down economic progress. Two types of financial distortions are particularly acute in Latin America and the Caribbean and are amenable to policy action. First, banks do not have access to quality information about potential borrowers. While the region has made progress in extending the coverage of credit bureaus that provide this information, the quality and timeliness of the information available through such bureaus is still poor in many countries. On average, the regulatory framework in Latin America is less conducive to information sharing than in other regions of the world.

A second problem is the high cost of enforcing financial contracts in the region. The effective protection of property rights is particularly weak in Latin America. The good news is that examples of 
successful reforms in the region have helped alleviate this constraint. Bankruptcy reforms in Brazil (2004-05), Colombia (2012), and more recently Chile (2014) appear to be lowering the costs of enforcing financial contracts.

\section{The Many Faces of Saving}

This book considers how changes in the different components of saving (see Box 1.1) contribute to total saving and investment in the overall economy. This approach allows a more comprehensive understanding of how public policies can affect saving by households, firms, and government agencies, while recognizing the important interrelationships between the different components. There are four possible interrelationships to consider:

- Between private and public saving. While government thrift would increase public saving, this usually leads to an offset in private saving because households and firms anticipate that with higher government saving today, lower taxes will be required in the future, and therefore they increase consumption today.

- Between household and firm saving. Households, which own firms, may factor firms' saving decisions into their own consumption decisions. Thus, higher saving by firms may be offset by lower saving by households.

- Between mandatory and voluntary household saving. Households may choose how much to save for retirement, using both pension and nonpension saving instruments interchangeably. Therefore, any saving done through pension instruments may just be forgone saving through other instruments.

- Between national and foreign saving. If national and foreign saving were perfect substitutes, a shortage of national saving would simply be made up by higher imports of foreign saving.

Box 1.2 discusses the theoretical and empirical evidence for each of these interrelationships. Here, suffice it to say that the collective evidence indicates that multiple possible offsets are only partial. Thus, increases in either public or private saving will increase national saving, but not on a one-to-one basis. And an increase in national saving will support higher domestic investment. 


\section{A Policy Agenda for the Future}

The book identifies six strategic goals for households, firms, and governments in the region.

First, governments must create an enabling environment for saving. This should become a high priority in the region's policy agendas. The "saving glut" in other parts of the world will not make up for the saving deficit in the region because foreigners cannot be expected to invest for the long term in countries where their own citizens are not confident enough to save.

Second, governments across the region can generate more saving by spending more efficiently. In fact, during difficult economic times, targeting public expenditures may be the only politically viable way to increase public saving in many countries because it avoids the unpleasantries of traditional fiscal tightening such as raising taxes or cutting expenditures.

Third, governments should promote and facilitate the development of financial systems that offer a full range of saving and investment instruments for households and firms. Banks can support these efforts by reaching out to more people with better financial instruments.

Fourth, governments, pension regulators, supervisors, and public and private sector managers must collaborate to fix broken pension systems. Population aging poses a great threat to economic stability and prosperity. Pension systems across the region must become sustainable, equitable, and more inclusive.

Fifth, people in Latin America and the Caribbean must develop a saving culture. Saving is difficult because it involves sacrificing current consumption. If people do not internalize the benefits of saving more, it will be hard, or impossible, to overcome inertia. Right now, too many people across the region fail to see the benefits of saving. A culture is built from the bottom up. Starting early in life with financial education on the role of saving is a critical element for success.

Sixth, saving more will not be enough to support development. The additional saving must be put to good use. The investment distortions that plague the region and that weaken investment demand must be eliminated. These distortions include inefficiencies in financial markets, high informality in labor markets, lack of adequate and predictable regulations, and special tax regimes. These distortions squander economic resources and impede productivity growth, which in turn feeds low investment demand and reduces saving. 


\section{BOX 1.2. THE INTERRELATIONSHIPS BETWEEN THE COMPONENTS OF SAVING}

\section{Public versus Private Saving: Ricardian Equivalence}

Do increases in public saving increase national saving? Governments' actions on fiscal policy are usually offset by private saving. In fact, the offset could be one to one, under the conditions specified by Barro (1974) on "Ricardian Equivalence," such as complete capital markets and perfect foresight. For example, any increase in the fiscal deficit financed either by lower taxes or higher debt-both of which would leave permanent income of households unchanged- would result in an equivalent increase in household saving, such that the net impact on national saving would be null.

However, the conditions that would enable a perfect offset are too stringent. Since Barro's paper, the literature has focused on assessing the degree of offset. ${ }^{a}$ Estimates vary across studies, but they tend to cluster in the range of 0.4 to 0.6 , suggesting that for every dollar by which public saving is reduced, private saving tends to increase by 40 to 60 cents. ${ }^{b}$ While the offset is significantly less than one to one, the fact that there is a partial offset suggests that putting the burden of rising national saving on fiscal policy alone is wrong. Governments should not overlook policies to mobilize private savings as well.

\section{Firm versus Household Saving: Piercing the Corporate Veil}

Within the private sector, part of the saving is generated by households and another portion by firms through retained earnings. Poterba (1987) noted that firms contributed a high share of private saving in the United States and went on to posit the "corporate veil hypothesis," according to which households take full account of the saving made by businesses: that is, households "pierce" the corporate veil.

The argument rests on the fact that households are the ultimate owners of firms, and thus they adjust their saving plans in accordance with changes in firms' saving decisions. However, various problems can invalidate the full piercing of the corporate veil in practice, such as asymmetric information and bounded rationality (Poterba, 1987). The resulting empirical prediction was that an increase (reduction) in firm saving will give rise to an increase (reduction) in private saving, albeit not one to one.

A handful of papers have researched the empirical nexus between household and firm saving, concluding that the offset is only partial. Grigoli, Herman, and Schmidt-Hebbel (2014) find that an additional dollar of firm saving translates into an increase of 42 cents in private saving. Using a different sample, Bebczuk and Cavallo (2016) find that a $\$ 1$ increase in firm saving reduces household saving by 40 cents-thereby increasing private saving by as much as 60 cents. 
BOX 1.2. (continued)

The bottom line is that the saving decisions of households and firms are intertwined. An association between the two sectors should be taken into account, but the two forms of saving are not perfect substitutes.

\section{Mandatory versus Voluntary Household Saving: The Pension Offset}

Household saving includes a mandatory component in the form of pension contributions. The potential substitutability between mandatory and voluntary saving matters for policy. If they were perfect substitutes, then retirement policies would have no incidence on the level of saving: that is, every dollar saved through a pension instrument would be offset by an equal amount of forgone saving in nonpension instruments. What is the extent of the offset in practice? In this area as well, the evidence points to only partial substitution, although the magnitude remains contested. ${ }^{c}$

This is a relevant and contentious policy issue in Latin America and the Caribbean. Beginning in the 1980s, the region was a pioneer in reforming pension systems from unfunded pay-as-you-go to fully funded regimes based on individual accounts. The objectives of the reforms were to increase pension coverage and reduce long-term fiscal vulnerabilities associated with the old systems. The reforms were also expected to increase private and national saving.

With the benefit of hindsight, researchers can evaluate the extent to which saving increased in the aftermath of the reforms. The evidence shows that private saving rose only moderately. ${ }^{d}$ The increase in private saving was weak because the number of contributors to the reformed systems remained low, as, in turn, informality in labor markets remained high. In addition, the reforms created a deficit during the transition period (to fulfill the promises made to people who had contributed to the old systems) that persists in several countries, and that lessened the positive impact of the reforms on national saving.

\section{Foreign versus National Saving: Imperfect Substitutes}

There is a high positive correlation between national saving and domestic investment across countries (Feldstein and Horioka, 1980). Numerous studies have found- with very few exceptions-that the correlation is systematically greater than zero across countries and over time. The positive correlation reveals imperfect financial integration across countries: changes in national saving are not completely offset by changes in foreign saving. Therefore, while the correlation does not prove if higher national saving leads to investment or vice versa, it does underscore that an increase in national saving can be expected to be at least partially retained domestically, thereby ending up as additional investment, rather than completely exported abroad through capital flight. 
BOX 1.2. (continued)

For countries that need to raise domestic investment, the robust positive correlation between national saving and domestic investment shows that recourse to importing foreign saving can be a helpful remedy, but is not a cure to low national saving. This conclusion is reinforced by two additional pieces of evidence presented in this book. First, for most countries, the net absorption of foreign saving is small relative to the volume of domestic investment (see chapter 2). Second, the financing of the domestic capital stock in each country has been predominantly national. ${ }^{\mathrm{e}}$

\footnotetext{
a For a recent survey of the literature, see Röhn (2010).

${ }^{b}$ Background research conducted in the context of this project confirms this range. Becerra, Cavallo and Noy (2015) conduct reduced form regressions of the determinants of private saving rates using panel regressions. One of the determinants of private saving is the public saving rate. Their coefficient estimate on public saving is approximately -0.60 , in line with previous estimates in the literature.

c Two strands of the literature have tested this hypothesis. The first strand analyzes the relationship between pension wealth and private savings using country case studies. Attanasio and Rohwedder (2003) and Attanasio and Brugiavini (2003) find evidence for Italy and the United Kingdom of a high degree of substitution between pensions and voluntary saving. For some groups of workers, the elasticity of substitution is close to 0.9. Using similar methods, Coronado (1998), Aguila (2011), and Sandoval-Hernández (2012) find high offset coefficients for workers in Chile and Mexico. The second strand exploits cross-country evidence of variation of pension arrangements (and saving) and aggregate saving. Examples include Bailliu and Reisen (1998); López-Murphy and Musalem (2004); Bebczuk and Musalem (2006); Clements et al. (2011); and Bebczuk (2015a). A common thread across these studies is that they uncover a positive but very small impact of funded pension regimes on nonpension saving.

d See Bebczuk (2015a).

e Aizenman, Pinto, and Radziwill (2007) show that on average 90 percent of the stock of physical capital in developing countries has been self-financed through the accumulation of national savings. Background research conducted for this book confirms this result for Latin America and the Caribbean.
}

In the end, measuring success in achieving these goals boils down to creating an environment where everybody shares the vision that more saving, and a better use of existing savings, is the solution to the region's economic woes-and the path to a stable and confident region in which any aspiration is possible. 


\section{Notes}

1 See Commission on Growth and Development (2008).

2 See Cavallo, Sánchez, and Valenzuela (2016).

3 See World Bank (2014b).

4 Corbacho, Fretes Cibils, and Lora (2013).

5 See World Bank and PwC (2015).

6 See Juárez (2009).

7 Integrating corporate and personal income taxes proved to be very successful in encouraging saving in Chile. See Cerda et al. (2015).

8 For example, the dual income tax in Nordic countries combines a flat tax on capital income with a progressive labor income tax schedule. Several countries in Latin America and the Caribbean have a dual or semi-dual system, but most are not integrated (Corbacho, Fretes Cibils, and Lora, 2013).

9 Corporate income tax rates have declined over the last 40 years from an average of 40 percent in 1980 to about 30 percent in the 2000s, and to 24 percent in 2014. Among the reasons for the decline, ongoing research points to profit-shifting concerns and the attraction of investment and tax competition.

10 High taxation of formal firms can lead to both less saving and lower formal employment. In Colombia, Granda and Hamann (2015) show that lower taxes on profits increase firm saving in the formal sector, and increase labor formalization and entrepreneurship. Reducing payroll taxes achieves similar qualitative results.

11 See OECD (2007); McDonald et al. (2011); Boadway (2015).

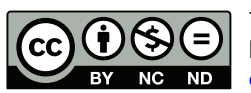

This chapter is distributed under the terms of the Creative Commons Attribution-NonCommercial-NoDerivatives 3.0 IGO license (http://creative commons.org/licenses/by-nc-nd/3.0/igo/) and may be reproduced with attribution to the Inter-American Development Bank (IDB) and for any non-commercial purpose. No derivative work is allowed.

Any dispute related to the use of the works of the IDB that cannot be settled amicably shall be submitted to arbitration pursuant to the UNCITRAL rules. The use of the IDB's name for any purpose other than for attribution, and the use of IDB's logo shall be subject to a separate written license agreement between the IDB and the user and is not authorized as part of this CC-IGO license. Note that the link provided above includes additional terms and conditions of the license.

The images or other third party material in this chapter are included in the work's Creative Commons license, unless indicated otherwise in the credit line; if such material is not included in the work's Creative Commons license and the respective action is not permitted by statutory regulation, users will need to obtain permission from the license holder to duplicate, adapt or reproduce the material. 